\title{
MANAGEMENT OF THE WHITE-CLAWED CRAYFISH (AUSTROPOTAMOBIUS PALLIPES) IN WESTERN FRANCE: ABIOTIC AND BIOTIC FACTORS STUDY
}

\author{
M.C. TROUILHE (1), F. RICARD (1), B. PARINET (2), F. GRANDJEAN (1), \\ C. SOUTY-GROSSET (1)
}

(1) Université de Poitiers, Laboratoire de Génétique et Biologie des Populations de Crustacés, UMR-CNRS 6556, 40, avenue du Recteur Pineau, 86022 Poitiers Cedex, France.

E-Mail: marie.cecile.trouilhe@etu.univ-poitiers.fr

(2) École Supérieure d'Ingénieurs de Poitiers, Laboratoire de Chimie de l'Eau et de l'Environnement, UMR-CNRS 6008, 40, avenue du Recteur Pineau, 86022 Poitiers Cedex, France.

Reçu septembre 2003

Accepté le 22 décembre 2003

Received September, 2003 Accepted December 22, 2003

\begin{abstract}
In France, the distribution of the white-clawed crayfish, Austropotamobius pallipes (Lereboullet, 1858), is restricted, fragmented and mainly located in headwaters. To preserve this indigenous species, it is necessary to characterize its ecological requirements (water and habitat quality). With this aim in view, a two-year study is being conducted in the Deux-Sèvres department (Western France) since November 2002. Nine brooks from four different catchments are monitored regularly; eight of the nine brooks harbour whiteclawed crayfish populations. Two sampling sites are surveyed per brook, the first being where the crayfish population is located and the second 2 to $3 \mathrm{~km}$ downstream. Physicochemical parameters (18) are measured twice monthly and biotic factors are estimated twice yearly. In this study, the I.B.G.N. (Indice Biologique Global Normalisé) protocol based on the determination of macroinvertebrates was used as a biotic index of biological water quality. Results of this preliminary study on two brooks (Thouet and Verdonnière) show that physico-chemical and biological data considered separately do not provide reliable information about $A$. pallipes ecological requirements. However, the use of multivariate analyses (Principal Component Analysis) to combine abiotic and biotic factors highlights a good correlation between these parameters. Organic matter appears to be a better discriminating factor than mineral matter affecting presence or absence of the whiteclawed crayfish.
\end{abstract}

Key-words: Austropotamobius pallipes, water quality, biotic index, macroinvertebrates, Principal Component Analysis (PCA). 


\title{
GESTION DE L'ÉCREVISSE À PATTES BLANCHES (AUSTROPOTAMOBIUS PALLIPES) DANS L'OUEST DE LA FRANCE : ÉTUDE DES FACTEURS BIOTIQUES ET ABIOTIQUES
}

\begin{abstract}
Résumé
En France, la distribution de l'écrevisse à pattes blanches, Austropotamobius pallipes (Lereboullet, 1858), est réduite, fragmentée et principalement située en tête de bassin. Afin de préserver cette espèce indigène, il est nécessaire de caractériser ses exigences écologiques (qualité de l'eau et de l'habitat). Dans ce but, une étude de deux ans est menée dans le département des Deux-Sèvres (Ouest de la France) depuis novembre 2002. Neuf ruisseaux sur quatre bassins hydrographiques différents sont régulièrement visités. Deux sites de prélèvements par ruisseau sont prospectés, le premier site est localisé au niveau de la population d'écrevisses et le second 2 à $3 \mathrm{~km}$ en aval. Les paramètres physico-chimiques (18) sont mesurés deux fois par mois et des facteurs biotiques sont estimés bi-annuellement. Dans cette étude, le protocole de l'I.B.G.N. (Indice Biologique Global Normalisé) basé sur la détermination de macroinvertébrés a été utilisé comme facteur biotique pour estimer la qualité biologique de l'eau. Les résultats de cette étude préliminaire sur deux ruisseaux (Thouet et Verdonnière) montrent que les données physico-chimiques et biologiques prises séparément ne fournissent pas d'informations fiables quant aux exigences écologiques d'A. pallipes. Cependant, l'utilisation d'analyses multivariées (Analyse des Composantes Principales) pour combiner les facteurs abiotiques et biotiques révèle une bonne corrélation entre ces paramètres. Ainsi, il semble que la matière organique soit un meilleur facteur discriminant que la matière minérale en ce qui concerne la présence ou l'absence de l'écrevisse à pattes blanches.
\end{abstract}

Mots-clés: Austropotamobius pallipes, qualité de l'eau, indice biotique, macroinvertébrés, Analyse des Composantes Principales (ACP).

\section{INTRODUCTION}

The white-clawed crayfish, Austropotamobius pallipes (Lereboullet, 1858), has a widespread distribution in Western Europe (HOLDICH, 2002). A. pallipes mainly occurs in headwaters and, over the last few decades, the distribution of this species has become restricted and fragmented due to several factors such as crayfish plague and degradation of water quality influenced by human activities (HOLDICH and ROGERS 1997; VIGNEUX, 1997). In France, this species appears to be demanding in terms of water and habitat quality (GRANDJEAN et al., 1996, 2000). Since 1983, A. pallipes has been listed as vulnerable on the red list of threatened animals of the International Union for the Conservation of Nature and Natural Resources (BAILLIE and GROOMBRIDGE, 1996). The white-clawed crayfish is also listed in annexes II and V of European Community Directives for the Conservation of Natural Habitats and Wild Flora and Fauna (92/43/EEC and 97/62/EU). This requires the establishment of management plans to conserve both threatened species and their biotope (VIGNEUX, 1997).

Over the last two decades, there have been several French studies to characterize the physico-chemical or biological requirements of $A$. pallipes (ARRIGNON and ROCHE, 1983; GRANDJEAN et al., 1996, 2000, 2001; NEVEU, 2000a, b; BROQUET et al., 2002).

Nevertheless, the use of only physico-chemical or biological parameters provides an oversimplified understanding of water quality. The recent combination of chemical and biological methods constitutes a better approach for an integrated assessment of freshwater quality (LAZARIDOU-DIMITRIADOU et al., 2000). Indeed, ecological indices 
may have several purposes and give complementary information to those obtained with physico-chemical data. They can be used to assess the condition of the environment or to monitor trends in condition over time. They can provide an early warning signal of changes in environment and they can also be used to diagnose the cause of an environmental problem (DALE and BEYELER, 2001). In this study, the French I.B.G.N. (Indice Biologique Global Normalisé, AFNOR 1992) was chosen to assess water quality based on the occurrence of macroinvertebrates.

The aim of this study is to characterize the ecological requirements (habitat and water quality) of $A$. pallipes in order to explain its current restricted and fragmented distribution in the Deux-Sèvres French department. Multivariate analyses (Principal Component Analysis) are used to examine the relationships between abiotic and biotic parameters. This paper presents preliminary results conducted on two brooks from this department (Thouet and Verdonnière) since November 2002.

\section{MATERIAL AND METHODS}

\section{Study sites}

The study was conducted in two French brooks (Thouet and Verdonnière, DeuxSèvres department) closely located in the Thouet catchment (Figure 1). Two sampling sites were monitored per brook: the first being where the population of white-clawed crayfish was present and the second about $2 \mathrm{~km}$ downstream of the population. The Thouet site harbouring crayfish (named site 1) was located $2 \mathrm{~km}$ from the source: banks were overgrown by alders (Alnus sp.). The surrounding vegetation was quite important, providing shade. The Thouet site without crayfish (site 2) also had similar vegetation and shade. In the Verdonnière site with crayfish (site 3), the vegetation of the right bank consisted of hazel trees while no vegetation was found on the left bank, thus the stream was more exposed to sunlight than both Thouet sites. The Verdonnière site without $A$. pallipes (site 4) is located near the confluence of the two studied brooks. The site was fairly sunny, banks were not altered and the vegetation was mainly of alders.

Stones, shingle and coarse gravel were the major substrate in the Thouet site with crayfish. In the Thouet site without crayfish, the substrate was essentially composed of leaf litter, roots and coarse gravel. In the Verdonnière site harbouring the whiteclawed crayfish, stones, shingle and coarse gravel were also predominant. The last site, Verdonnière without crayfish, presented the most heterogeneous substrate with a codominance of litter, roots, stones, shingles, coarse gravel, sand and silt. All these data were summarized in Table I.

\section{Physico-chemical parameters}

For each site, eighteen physicochemical parameters were measured twice monthly since November 2002. Methods and analytic technologies applied in this study were normalized. In situ measurements of temperature $(\mathrm{T})$, dissolved oxygen $\left(\mathrm{O}_{2}\right), \mathrm{pH}$, conductivity (Cond) and redox potential (E) were recorded using a digital meter (WTW) with the appropriate probes. Water turbidity (Turb) was also measured using a $\mathrm{HACH}$ Pocket Turbidimeter Cat. No. 52600-00

In the laboratory, water samples were filtered through a $0.45 \mathrm{~mm}$ "millipore" membrane and were analysed for Sodium ( $\mathrm{Na}$ ), Potassium (K), Chlorures $(\mathrm{Cl})$, Nitrates $\left(\mathrm{NO}_{3}\right)$, Nitrites $\left(\mathrm{NO}_{2}\right)$ and Sulphates $\left(\mathrm{SO}_{4}\right)$. Total Organic Carbon (TOC), UV $(254 \mathrm{~nm})$, fluorimetry (Fluo) and Ammonium $\left(\mathrm{NH}_{4}\right)$ analyses were carried out on unfiltered samples. Total Suspended Solids (TSS) were measured as the weight of material retained by the fibreglass filters. 

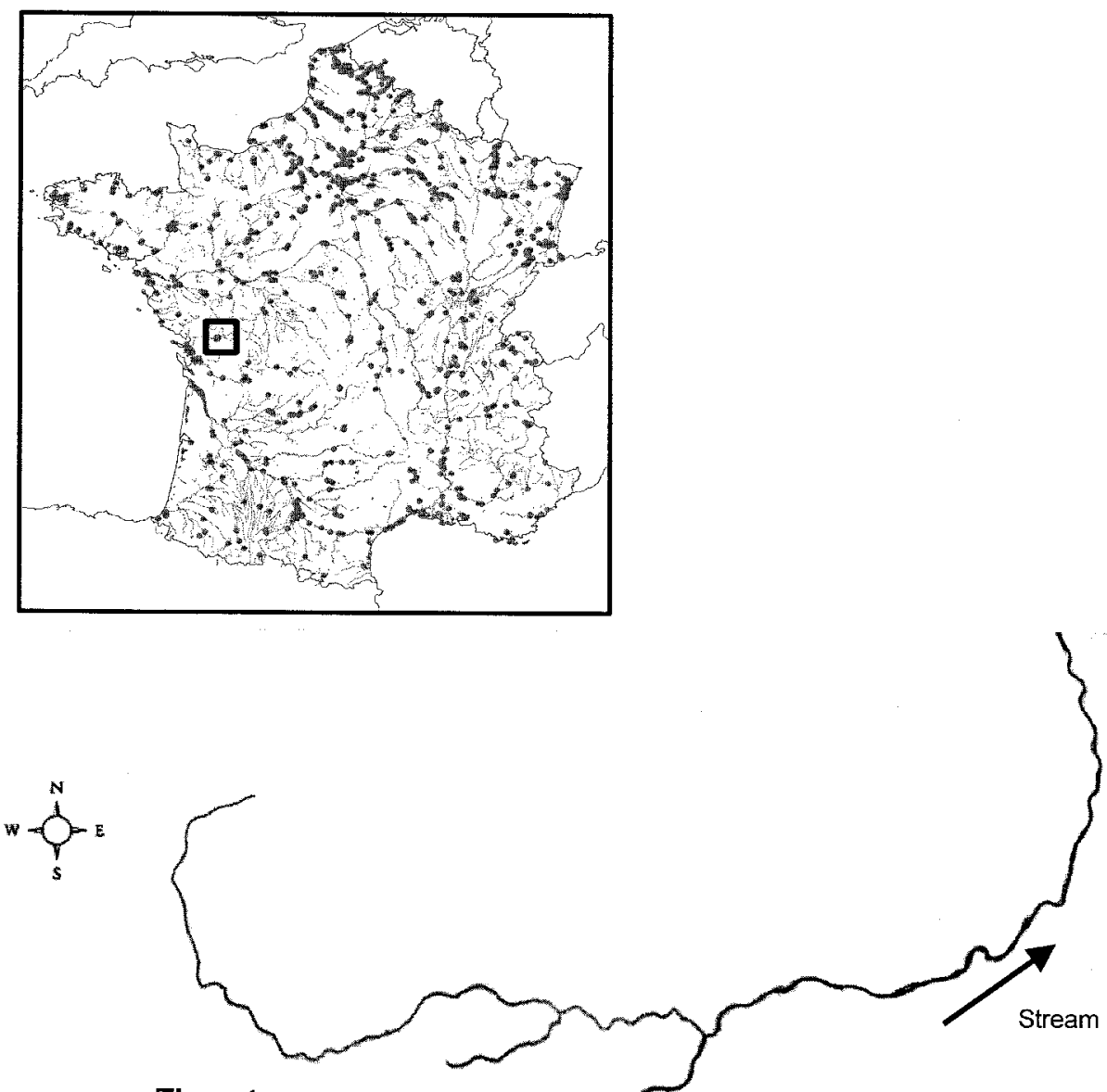

1
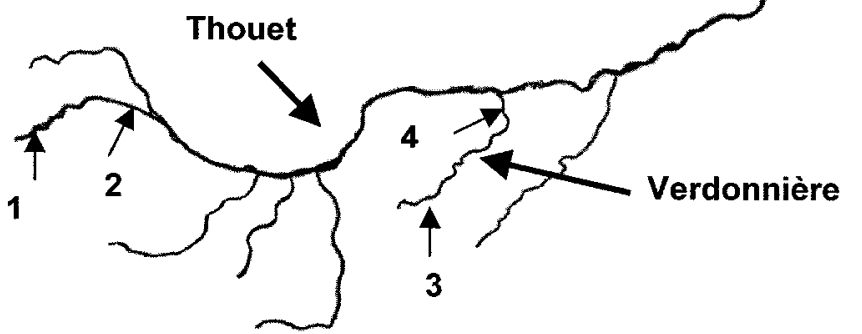

$1,5 \mathrm{~km}$

Figure 1

Location of the two brooks sampled in the Deux-Sèvres département (France). The 4 sampled sites are reported as follows: 1 , Thouet with crayfish; 2 , Thouet without crayfish; 3 , Verdonnière with crayfish and 4 , Verdonnière without crayfish.

\section{Figure 1}

Localisation des deux cours d'eau étudiés dans le département des DeuxSèvres (France). Les 4 sites échantillonnés sont reportés comme suit : 1, Thouet avec écrevisses ; 2, Thouet sans écrevisse ; 3 , Verdonnière avec écrevisses et 4, Verdonnière sans écrevisse. 


\section{Table I}

Experimental protocol of sampling according to the I.B.G.N. method. The 8 samples per sites are reported in this table for the 4 studied sites: 1, Thouet with crayfish; 2, Thouet without crayfish; 3, Verdonnière with crayfish and 4 , Verdonnière without crayfish. Numbers in brackets indicate the number of samples taken from a same substrate for each site.

\section{Tableau I}

Protocole expérimental de prélèvement selon la méthode de I'I.B.G.N. Les 8 prélèvements pour les 4 sites sont représentés dans ce tableau: 1, Thouet avec écrevisses; 2, Thouet sans écrevisse ; 3 , Verdonnière avec écrevisses et 4 , Verdonnière sans écrevisse. Les chiffres entre parenthèses indiquent le nombre de prélèvements effectués sur un même substrat pour chacun des sites.

\begin{tabular}{|c|c|c|c|c|c|c|}
\hline \multirow[t]{2}{*}{ Substrates } & & \multicolumn{5}{|c|}{ Superficial speed V $\left(\mathrm{cm} . \mathrm{s}^{-1}\right.$} \\
\hline & & $>150$ & $150>V>75$ & $75>V>25$ & $25>$ V 5 & $V<5$ \\
\hline Bryophyles & 9 & & & 3 & & \\
\hline Submerged spermatophyles & 8 & & & & & \\
\hline Litter, roots & 7 & & & & & $1(\times 2)-2(\times 3)-4(\times 2)$ \\
\hline $\begin{array}{l}\text { Stones, shingle } \\
250 \mathrm{~mm}>\mathrm{d}>25 \mathrm{~mm}\end{array}$ & 6 & & & $1(\times 3)-3(\times 3)-4$ & 4 & \\
\hline $\begin{array}{l}\text { Coarse gravel } \\
25 \mathrm{~mm}>\mathrm{d}>2,5 \mathrm{~mm}\end{array}$ & 5 & & & $2(\times 2)-3(\times 2)-4$ & $1(\times 2)-2$ & 4 \\
\hline $\begin{array}{l}\text { Emergent spermatophytes of } \\
\text { low substratum }\end{array}$ & 4 & & & & & \\
\hline $\begin{array}{l}\text { Fine sediment } \\
\mathrm{d}<0,1 \mathrm{~mm}\end{array}$ & 3 & & & & & \\
\hline $\begin{array}{l}\text { Sand and silt } \\
\mathrm{d}<2,5 \mathrm{~mm}\end{array}$ & 2 & & & & $2-3-4(\times 2)$ & $1-3$ \\
\hline $\begin{array}{l}\text { Artificial or natural substrates } \\
\text { (rocks, flags, soils) blocs } \\
d>250 \mathrm{~mm}\end{array}$ & 1 & & & & & \\
\hline Algae or clay & 0 & & & & & 2 \\
\hline
\end{tabular}

\section{Use of Principal Component Analysis (PCA)}

Multivariate analyses were applied using Principal Component Analysis (PCA). The analyses were carried out with the SPSS 11.0 for Windows statistical package (SPSS Inc., Microsoft Co.).

\section{Macroinvertebrate sampling and biotic scores}

The French IBGN (Indice Biologique Global Normalisé) method (AFNOR, Norm NF T 90-350, 1992), which is based on the occurrence of macroinvertebrates, was adopted to estimate biological water quality. In March 2003, eight samples were taken at each of the four sites using a standard Surber net (surface: $500 \mathrm{~cm}^{2}$ and mesh size: $500 \mu \mathrm{m})$ following VERNEAUX et al. (1983). The reference-sampling table was used to sample the habitats of each site taking into account the nature of the substrate and the speed of the water. The order of sampling followed the substrate list order, which is based on the abilities of the different substrates to contain organisms ranging from bryophytes first to algae and clay last (Table I). Samples were preserved in $10 \%$ formaldehyde. In the laboratory, the macroinvertebrates were sorted using $500 \mu \mathrm{m}$ mesh sieves and identified to families (with the exception of Hydrozoa, Hydracarina and Oligochaeta).

The I.B.G.N. score for a site ranges on a scale from 0 to 20 where 0 indicates a high level of pollution and 20 no pollution. This score is based on a faunal list restricted to 
138 macroinvertebrate taxa of which 38 , in nine indicator groups, are indicators of water quality; group 9, including Plecoptera, is the most sensitive to pollution and group 1, including worms is the most tolerant. The score depends on both the number of taxa and the indicator groups recorded from the eight samples.

\section{Comparisons of macroinvertebrate fauna}

The Shannon's diversity index $(\mathrm{H})$ was used to estimate habitat diversity at each site (CHARVET, 1995). This index ranged from 0.5 for the least diversified habitat to 4.5 for the most. This index was calculated as follows:

$$
H=(1 / N)\left[N_{i}\left(\operatorname{Ln} N / \operatorname{Ln} 2-\operatorname{Ln} N_{i} / \operatorname{Ln} 2\right)\right]
$$

where $\mathrm{N}$ was the total number of individuals of a sampling site and $\mathrm{N}_{\mathrm{i}}$ the number of individuals of each taxon.

The Jaccard's similarity index (i) was used to assess the similarity of macroinvertebrate fauna between two sites (CHARVET, 1995). This index was not only applied to all recorded taxa but also to the most pollution sensitive taxa (Ephemeroptera, Trichoptera and Plecoptera). The Jaccard's similarity index was calculated as follows:

$$
\mathrm{I}=100 \times \mathrm{n}_{\mathrm{c}} /\left(\mathrm{n}_{\mathrm{i}}+\mathrm{n}_{\mathrm{j}}-\mathrm{n}_{\mathrm{c}}\right)
$$

where $n_{c}$ was the number of common taxa between two sites $i$ and $j, n_{i}$ the number of taxa of site $i$ and $n_{j}$ the number of taxa of site $j$.

\section{Trophic guilds}

The macroinvertebrate fauna was classified into 8 trophic guilds - shredders, collectors, scrapers, detritivore shredders, grazers, substrate feeders, suckers and predators - to provide insights into the nature of stream disturbance (MERRIT and CUMMINS, 1996).

The macroinvertebrate fauna was also classified according to two functional feeding patterns: autochthonous nutrition which was represented by taxa feeding on macroinvertebrates, macrophytes or algae (predators, grazers and substrate feeders) and allochthonous nutrition which was typical of taxa feeding on external supplies (collectors, shredders, detritivorous shredders).

\section{RESULTS}

\section{Physico-chemical parameters}

\section{In situ and laboratory measurements}

Table II summarises chemical and physical measurements for both sites. Averages of each parameter were computed from twice monthly measurements from November $5^{\text {th }}$ 2002 to May $7^{\text {th }}$ 2003. Average values of the different parameters were quite similar during the study period from a site to another one. Nevertheless some differences occurred into four parameters: Turbidity, $\mathrm{NH}_{4}$, TSS and UV. In both cases, the sites harbouring crayfish presented much lower values than the ones recorded on the site without crayfish. The Verdonnière samples from the site with crayfish presented a lower average for the four considered parameters than did those from Thouet with the white-clawed crayfish. Thouet and Verdonnière sites without $A$. pallipes showed higher Turbidity, $\mathrm{NH}_{4}$, TSS and UV mean values than the sites harbouring crayfish. 


\section{Table II}

Averages ( \pm standard deviation) and ranges of physical and chemical parameters measured on each sites between November $5^{\text {th }} 2002$ and May $7^{\text {th }} 2003$.

Tableau II

Moyennes ( \pm écarts-types) et étendues des paramètres physiques et chimiques mesurés sur chacun des sites entre le 5 novembre 2002 et le 7 mai 2003.

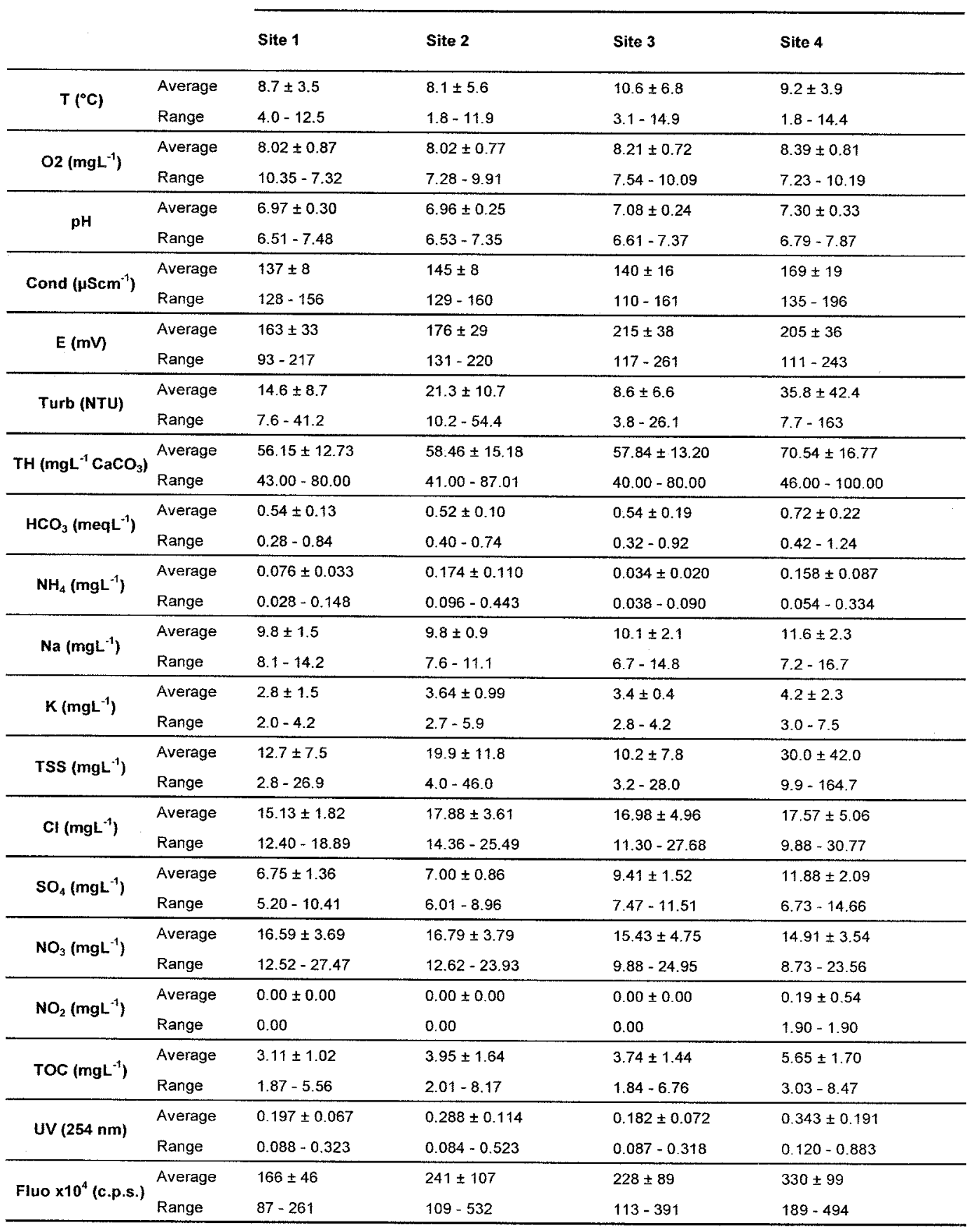




\section{Principal Component Analysis (PCA)}

All the analytical variables were well represented. The PCA showed that the first two principal components represented up to $53 \%$ of the total variance $\left(\mathrm{PC}_{1} 34 \%\right.$; $\left.\mathrm{PC}_{2} 19 \%\right)$ of the observations.

Figure 2 gives the projection of the various analytical variables in the principal plane. Component 1 was clearly built from the mineral variables $\left(\mathrm{Na}, \mathrm{SO}_{4}, \mathrm{Cl}\right.$, Alkalinity, Conductivity, $\mathrm{pH}$, etc...) in accordance with the geological substrates, while component 2 was largely built from the organic variables, except for potassium and for ammonium that was an indicator of domestic and/or agricultural pollution.

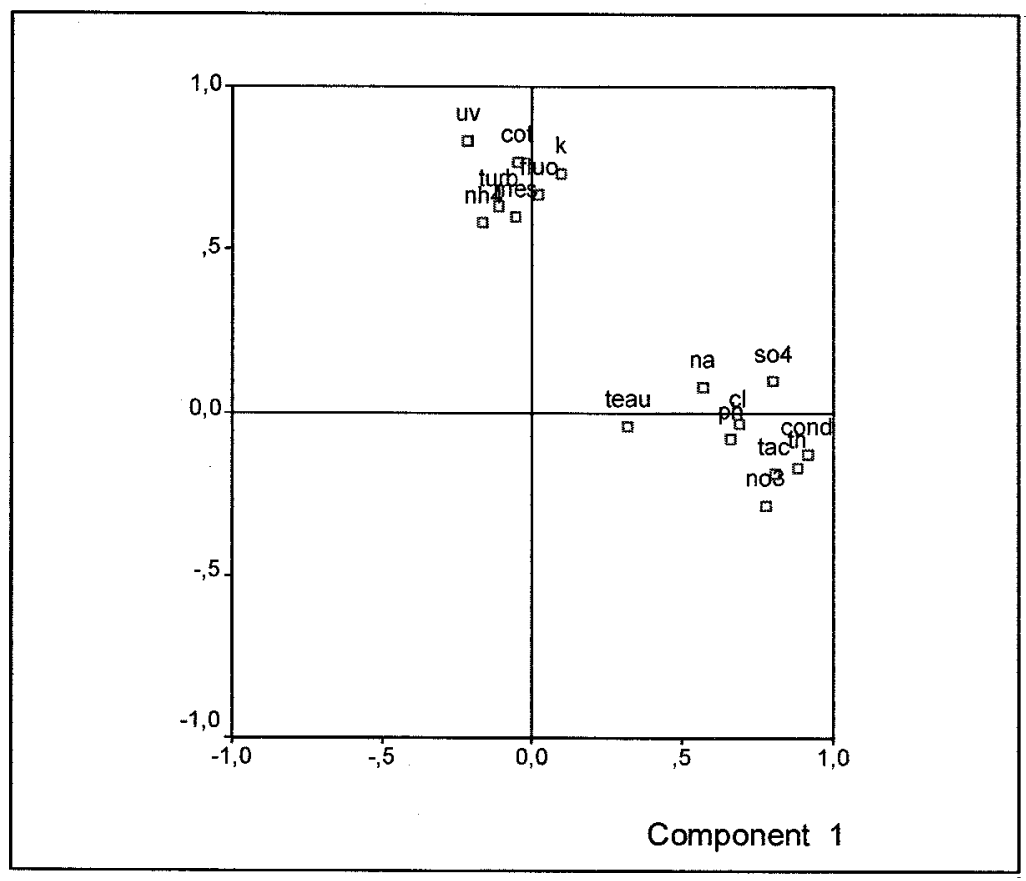

\section{Figure 2}

Plotting, with the use of PCA, of 16 experimental variables measured to the plane defined by the first two components.

\section{Figure 2}

Représentation, à l'aide d'une $\mathrm{ACP}$, de 16 variables expérimentales mesurées sur les ruisseaux du Thouet et de la Verdonnière selon le plan défini par les deux premières composantes.

\section{Macroinvertebrate fauna}

Table III lists the macroinvertebrates found at the four studied sites.

\section{Thouet}

The Thouet site containing crayfish yielded 3694 macroinvertebrates from 28 taxa (Table IV). Gammaridae (Crustacea) were dominant and represented $82 \%$ of the total number of individuals collected at this site. Six families of Diptera were represented. The E.T.P. (Ephemeroptera-Trichoptera-Plecoptera) group was represented by 10 taxa: 
4 families of Ephemeroptera, 5 of Trichoptera and 1 of Plecoptera. Among these orders, Baetidae and Limnephilidae were the most numerous (Table III). In the 28 taxa, 13 were rare (only represented by 1 or 2 individuals).

\section{Table III}

List of macroinvertebrates (8 samples) leading to the calculation of I.B.G.N. score for each site. IG = Indicator Group.

Table III

Liste des macroinvertébrés (8 prélèvements) servant au calcul de la note I.B.G.N. pour chacun des sites. IG = Groupe Indicateur.

\begin{tabular}{|c|c|c|c|c|c|}
\hline & IG & Site 1 & Site 2 & Site 3 & Site 4 \\
\hline \multicolumn{6}{|l|}{ Plecoptera } \\
\hline Nemouridae & 6 & 1 & & 38 & \\
\hline \multicolumn{6}{|l|}{ Trichoptera } \\
\hline Goeridae & 7 & 6 & 2 & 6 & \\
\hline Hydropsychidae & 3 & 2 & 15 & 1 & 1 \\
\hline Leptoceridae & 4 & & & & 1 \\
\hline Limnephilidae & 3 & 74 & 36 & 6 & 1 \\
\hline Philopotamidae & 8 & & & 4 & \\
\hline Polycentropodidae & 4 & & & & 2 \\
\hline Psychomyiidae & 4 & 2 & & & 5 \\
\hline Rhyacophilidae & 4 & 2 & & 9 & \\
\hline Sericostomatidae & 6 & & 11 & 15 & 4 \\
\hline \multicolumn{6}{|l|}{ Ephemeroptera } \\
\hline Baetidae & 2 & 96 & 46 & 497 & 6 \\
\hline Ephemerellidae & 3 & & 16 & 4 & 1 \\
\hline Ephemeridae & 6 & 1 & 13 & 2 & 2 \\
\hline Heptageniidae & 5 & 4 & & 37 & \\
\hline Leptophlebiidae & 7 & 8 & 10 & 29 & 1 \\
\hline \multicolumn{6}{|l|}{ Coleoptera } \\
\hline Elmidae & 2 & 47 & 88 & 22 & 27 \\
\hline \multicolumn{6}{|l|}{ Diptera } \\
\hline Athericidae & & & 4 & & 2 \\
\hline Chironomidae & 1 & 232 & 143 & 870 & 559 \\
\hline Culicidae & & 1 & & & \\
\hline Empididae & & & 2 & & \\
\hline Limoniidae & & 15 & 6 & 16 & \\
\hline Ptychopteridae & & 5 & & 10 & \\
\hline Rhagionidae & & & 1 & & \\
\hline Simuliidae & & 4 & & 42 & 4 \\
\hline Tabanidae & & 4 & 5 & & \\
\hline \multicolumn{6}{|l|}{ Odonates } \\
\hline Calopterygidae & & 2 & 17 & & 1 \\
\hline \multicolumn{6}{|l|}{ Megaloptera } \\
\hline Sialidae & & 1 & & & \\
\hline \multicolumn{6}{|l|}{ Crustacea } \\
\hline Gammaridae & 2 & 3039 & 3524 & 366 & 123 \\
\hline Asellidae & 1 & 2 & 2 & & 43 \\
\hline \multicolumn{6}{|l|}{ Mollusca } \\
\hline Sphaeriidae & 2 & 45 & & & 18 \\
\hline Ancylidae & 2 & & & & 2 \\
\hline Planorbidae & 2 & 2 & & & \\
\hline \multicolumn{6}{|l|}{ Acheta } \\
\hline Erpobdellidae & 1 & 1 & 5 & & 13 \\
\hline Glossiphoniidae & 1 & 2 & 1 & & 1 \\
\hline \multicolumn{6}{|l|}{ Triclades } \\
\hline Planariidae & & 27 & 1 & 10 & \\
\hline Oligocheta & 1 & 68 & 146 & 29 & 328 \\
\hline Pseudocoelomate phyla & & 1 & & & \\
\hline Hydracarina & & & & & 1 \\
\hline Nemerteans & & & 1 & & \\
\hline
\end{tabular}


The sample from the site without crayfish on Thouet included 4095 individuals representing 23 taxa (Table IV). Gammaridae was still the dominant taxon and represented $86 \%$ of the total number of individuals of the site. The highest diversity was recorded within the Diptera represented by 6 families. 8 families of Ephemoptera and Trichoptera (4 of each) were found and were represented by 149 individuals. Between these two orders, Baetidae and Limnephilidae were the most numerous (Table III). 7 of the 23 were rare.

\section{Verdonnière}

The Verdonnière samples from the site with the white-clawed crayfish contained 2013 individuals within 21 taxa (Table IV). Chironomidae (Diptera) represented $43 \%$ of the individuals. The order with the greatest family representation was the Trichoptera with 6 families. The resource of E.T.P. was composed of 12 taxa: 5 families of Ephemeroptera, 6 of Trichoptera and 1 of Plecoptera. Baetidae, Nemouridae and Heptageniidae were the best-represented families (Table III). Only 2 taxa of the 21 recorded were rare.

Downstream the white-clawed crayfish population of Verdonnière, 1146 individuals were recorded among 23 taxa (Table IV). Chironomidae were the most numerous taxon and represented $49 \%$ of the sampled macroinvertebrates. The highest diversity was again observed within the Diptera (6 families). This site harboured 4 and 6 families of Ephemeroptera and Trichoptera respectively. Within the E.T.P. group, Baetidae, Psychomyiidae and Sericostomatidae were the most sampled (Table III). Among the 23 recorded taxa, 12 were rare.

\section{Table IV}

Summary of the main results from macroinvertebrate study from the 4 sites.

\section{Tableau IV}

Résumé des principaux résultats obtenus par l'étude des macroinvertébrés sur les 4 sites.

\begin{tabular}{lcccc}
\hline & Site 1 & Site 2 & Site 3 & Site 4 \\
\hline Number of individuals & 3694 & 4095 & 2013 & 1146 \\
Number of taxa & 28 & 23 & 21 & 23 \\
Dominant taxa & Gammaridae & Gammaridae (3524) & Chironomidae (870) & Chironomidae (559) \\
Taxa with the highest diversity & Diptera (6) & Diptera (6) & Trichoptera (6) & Trichoptera (6) \\
Indicator taxa & Goeridae (7) & Leptophlebiidae (7) & Philopotamidae (8) & Sericostomatidae (6) \\
Domiant guild & Shredders & Shredders & Collectors, Grazers, Collectors, Suckers, \\
Shannon index & & & Shredders & Shredders \\
I.B.G.N. score & 1,22 & 1,02 & 2,36 & 2,1 \\
Water quality & 14 & 13 & 14 & 12 \\
\hline
\end{tabular}

\section{Comparisons of macroinvertebrate fauna}

The values of Shannon's diversity index applied to Thouet were quite low: 1.22 and 1.02 for site harbouring $A$. pallipes and site without crayfish respectively (Table IV). Values of 2.36 and 2.1 were recorded on similar sites on Verdonnière (Table IV).

Percentages similarities ranged from 37.50 to 53.33 when Jaccard's similarity index was applied to all taxa (Table V). The two sites without crayfish $(53.33 \%)$ showed the highest similarity and the two sites of Verdonnière (37.50\%) showed the lowest one. 
When Jaccard's index was applied to E.T.P. only, higher similarity percentages were recorded (Table V). The highest similarity was $69.23 \%$ between the two sites harbouring the white-clawed crayfish. The lowest recorded values were observed between the two sites on the same brook ( $50 \%$ and $46.67 \%$ for Thouet and Verdonnière respectively).

\section{Tableau V}

Macroinvertebrate fauna comparisons between the 4 sites using the Jaccard's similarity index. Bold characters only refer to Ephemeroptera, Trichoptera and Plecoptera fauna. Values are expressed in percentage.

\section{Tableau V}

Comparaisons de la faune de macro invertébrés entre les 4 sites à l'aide de l'indice de similarité de Jaccard. Les chiffres en gras ne tiennent compte que de la faune d'Éphéméroptères, de Trichoptères et de Plécoptères. Les valeurs sont exprimées en pourcentages.

\begin{tabular}{ccccc} 
& Site 1 & Site 2 & Site 3 & Site 4 \\
\hline Site 1 & 100 & 50.00 & 69.23 & 42.86 \\
\hline Site 2 & 45.71 & 100 & 66.67 & 63.64 \\
\hline Site 3 & 48.48 & 46.67 & 100 & 46.67 \\
\hline Site 4 & 45.71 & 53.33 & 37.50 & 100 \\
\hline
\end{tabular}

\section{I.B.G.N. scores}

I.B.G.N. scores ranged from 12 to 14 (Table IV). According to the I.B.G.N. protocol, the two sites of Thouet and the site harbouring crayfish of Verdonnière had good water quality whereas the Verdonnière site without crayfish had fair water quality. For both site of Thouet an indicator group of 7 was recorded; Goeridae (Trichoptera) and Leptophlebiidae (Ephemeroptera) were the most pollution sensitive taxa for Thouet and Verdonnière respectively (Table IV). For the Verdonnière site-harbouring crayfish the most pollution sensitive taxa was Philopotamidae (Trichoptera), which represented an indicator group of 8 . The Verdonnière site without crayfish showed an indicator group of 6 and Sericostomatidae (Trichoptera) was the most pollution sensitive taxa.

\section{Trophic guilds}

The distribution of individuals by trophic guild is illustrated for each site in Figure 3. Both Thouet sites showed a similar distribution of trophic groups, the dominant group being represented by shredders due to the high number of Gammaridae (85\% and $88 \%$ respectively).

Percentages of functional feeding groups were more balanced for Verdonnière (Figure 3). In the site harbouring the white-clawed crayfish, three major guilds were distinguished: collectors (46\%, Chironomidae, Diptera), grazers (25\%, Baetidae, Ephemeroptera) and shredders (24\%, Gammaridae, Crustacea). On the downstream site, three major guilds were also observed: collectors (51\%, Chironomidae), suckers $(29 \%$, Oligochaeta) and shredders (15\%, Gammaridae). 
The distribution of individuals according to functional feeding groups (autochthonous or allochthonous) is illustrated in Figure 4. For each brook, most macroinvertebrates had an allochthonous feeding pattern due to a high proportion of Gammaridae for Thouet and Chironomidae for Verdonnière.

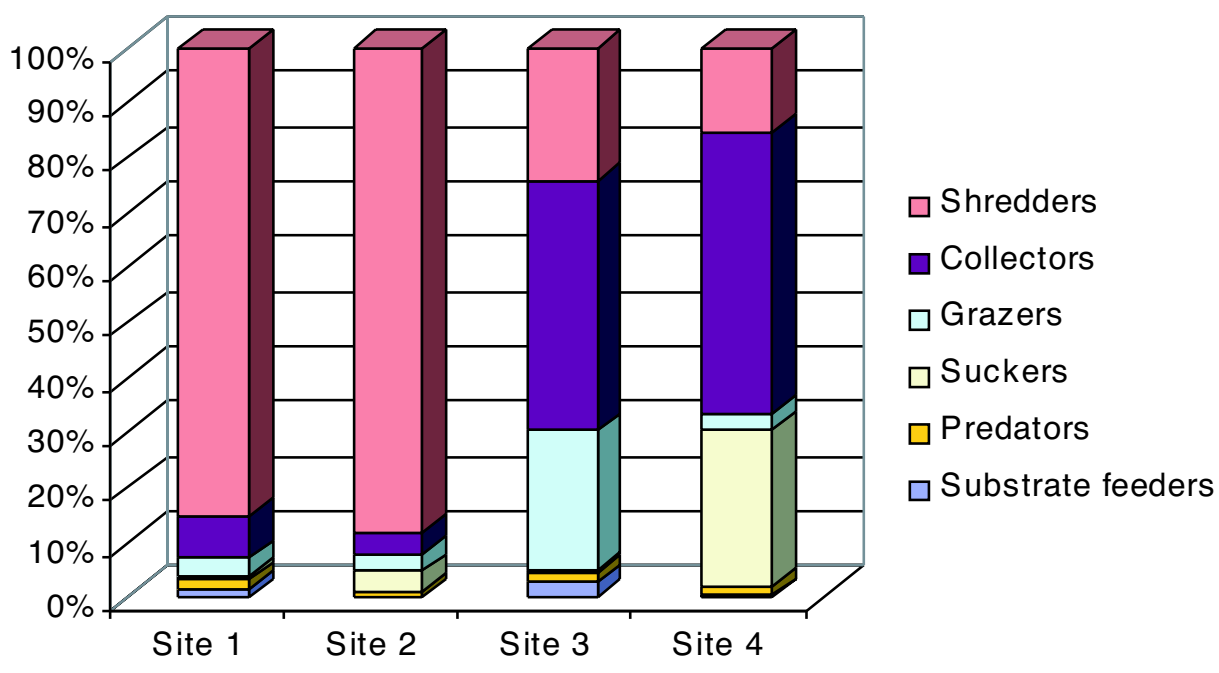

Figure 3

Distribution of trophic guilds from the macro invertebrate samples in the 4 sites.

\section{Figure 3}

Répartition des macroinvertébrés selon les différentes guildes trophiques dans les 4 stations.

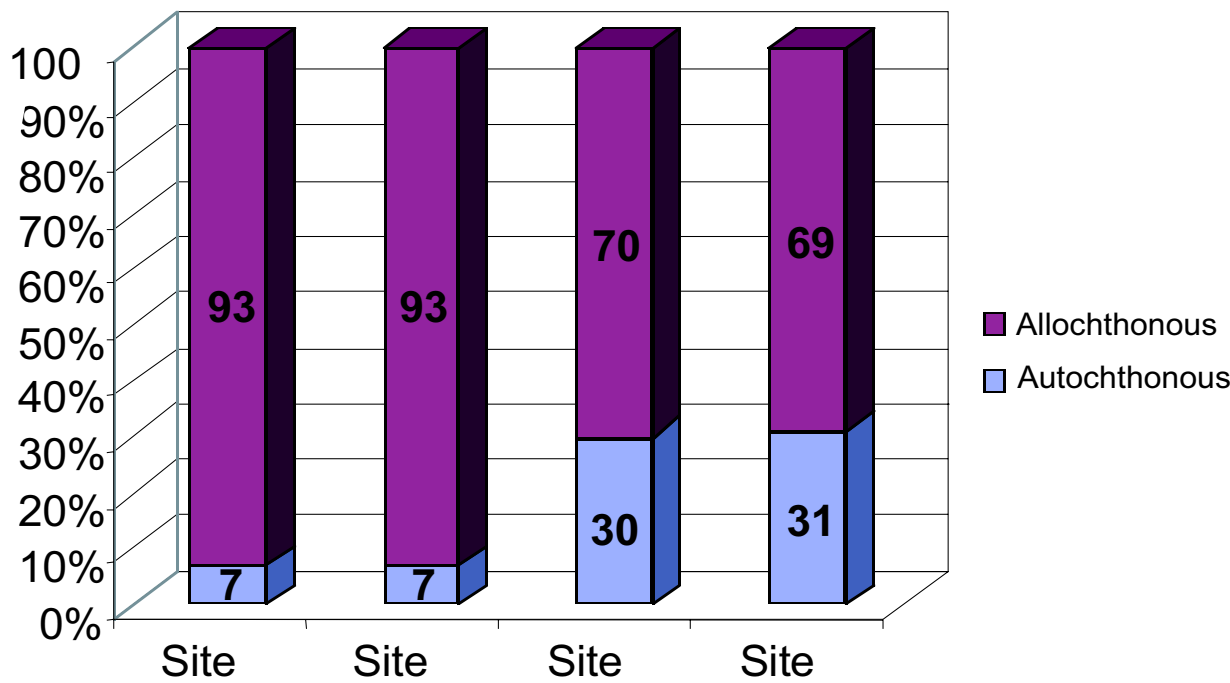

Figure 4

Distribution of macro invertebrates from the 4 sites according to their functional feeding groups: allochthonous or autochthonous.

Figure 4

Répartition des macroinvertébrés des 4 stations en fonction de leur mode de nutrition allochtone ou autochtone. 
Figure 5 shows a PCA plot of the variables measured for each sampling point during the study period. Each factor score has been associated to the corresponding I.B.G.N. score. The I.B.G.N. score decreased (arrow) in the direction of an increase in the organic character and to a lesser extent of the mineral character. Figure 6 shows under the same conditions the factor scores in relation to the presence or absence of crayfish. The limit of presence seems to be in the vicinity of an I.B.G.N. score of 13.

\section{Discussion}

Both sites harbouring the white-clawed crayfish showed good to fair water quality based on macroinvertebrates with I.B.G.N. scores ranging from 14 to 13 . These results are lower than I.B.G.N. scores previously reported by GRANDJEAN et al. (2001) for 5 brooks located nearby in the Deux-Sèvres department. These relatively low scores are explained by low taxon diversities of only 28 and 21 taxa. The absence of individuals of indicator groups 8-9 in the Thouet site harbouring the white-clawed crayfish also partly explains the score recorded on this site. This good but not optimal water quality estimate suggests that $A$. pallipes can live in brooks having sub-optimal water quality. GRANDJEAN et al. $(2000,2001)$ have already demonstrated this phenomenon in the same area, BROQUET et al., (2002) in the Pays de Loire région (France) and DEMERS and REYNOLDS (2002) in Ireland.

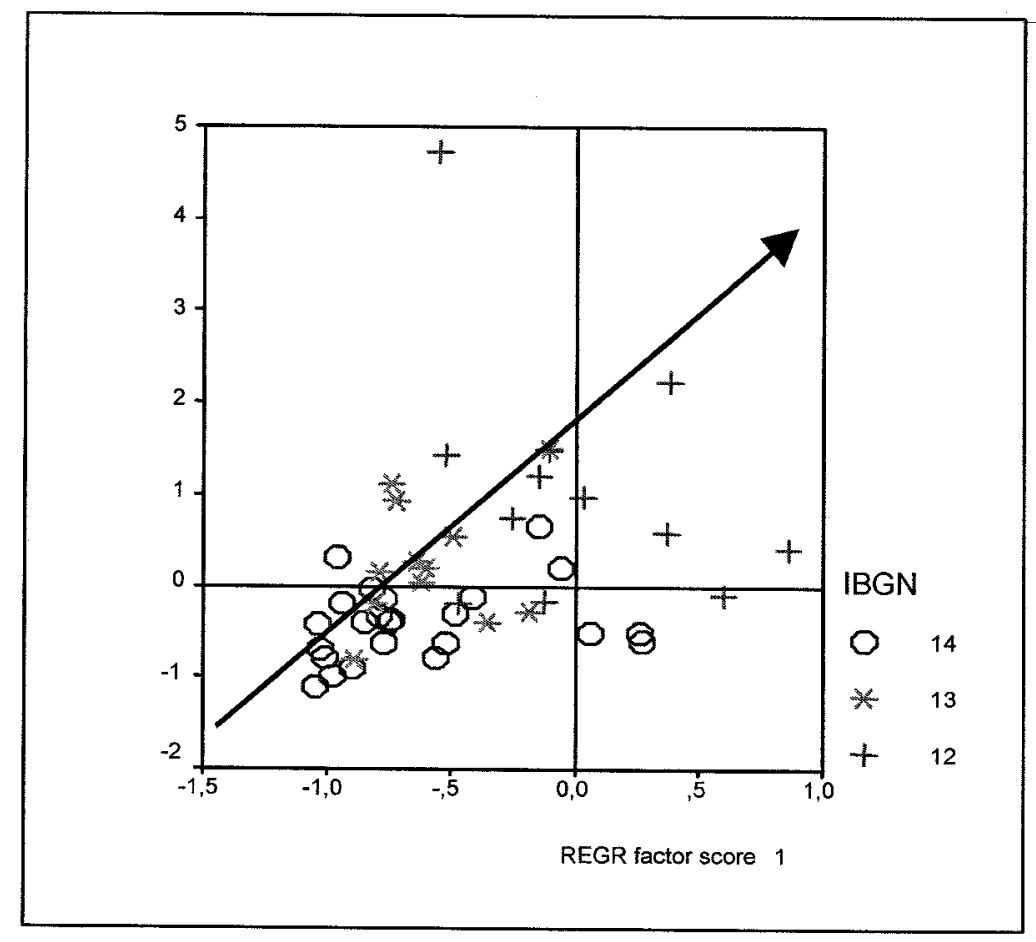

\section{Figure 5}

Plotting, with the use of PCA, of I.B.G.N. scores of the Thouet and Verdonnière brooks according to the plane defined by the first two components. The arrow direction shows an increase in the organic matter character.

\section{Figure 5}

Représentation, à l'aide d'une ACP, des notes I.B.G.N. sur les ruisseaux du Thouet et de la Verdonnière selon le plan défini par les deux premières composantes. La direction de la flèche indique une augmentation du facteur matière organique. 


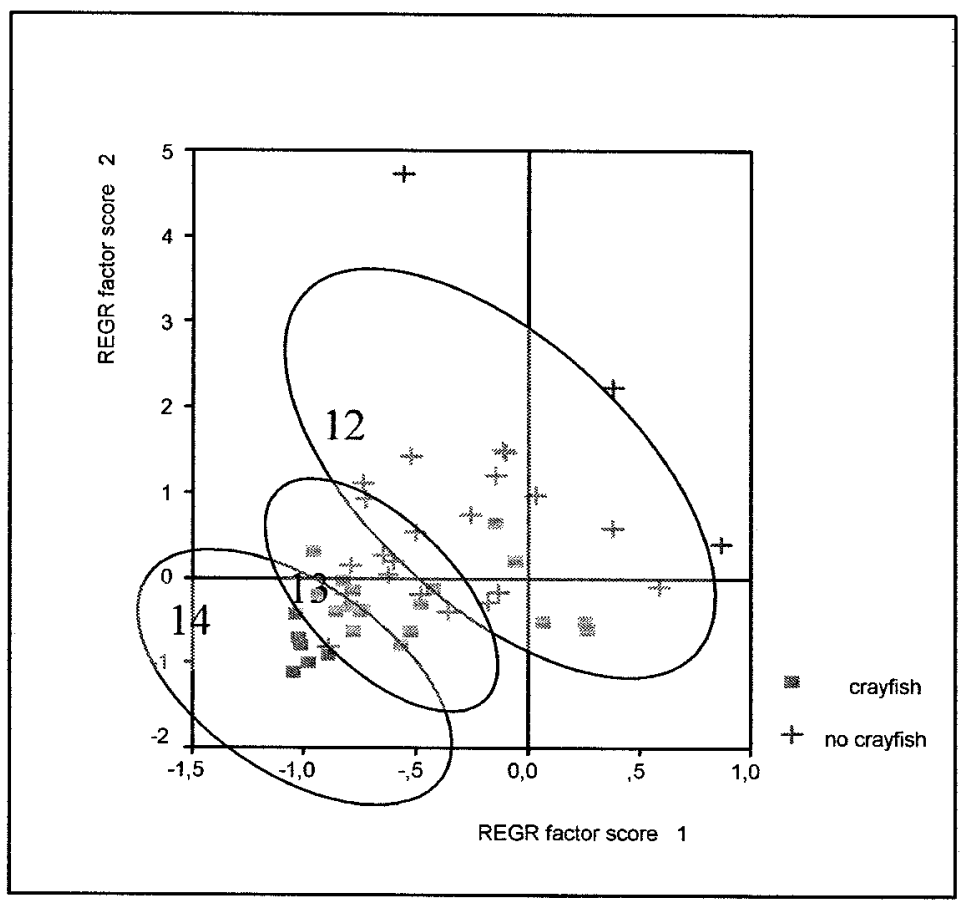

Figure 6

PCA plot of the I.B.G.N. scores for the Thouet and Verdonnière brooks in accordance with the white-clawed crayfish presence or absence.

\section{Figure 6}

ACP des notes I.B.G.N. des ruisseaux du Thouet et de la Verdonnière en fonction de la présence ou de l'absence de l'écrevisse à pattes blanches.

The high number of rare taxa (13) on the Thouet site harbouring the white-clawed crayfish shows that this environment is precarious because the score would drop to 11 if these rare taxa disappeared. In 2000 the situation was similar because DELVALLE et al. (2002) had estimated an I.B.G.N. score of 15 on this site with 15 rare taxa out of 31 total taxa. In the same way, the Verdonnière site without crayfish appears to be precarious presenting 12 rare taxa out of 23. In addition, a high number of Asellidae was recorded indicating a high level of dissolved organic matter. This observation is corroborated by the high values of Turbidity, TSS and TOC measured on this site. On the contrary, Verdonnière site with crayfish shows a very low rate of rare taxa (2/21) indicating a stable state of the environment.

The Shannon diversity index is always higher for sites harbouring $A$. pallipes. However, there is variation between these sites. Thus, Verdonnière Shannon index value is twice as high as the one recorded in the Thouet (2.36 and 1.22 respectively). The Jaccard's similarity index shows strong taxa similarity between sites of the order of $50 \%$. The similarity rate increases to $69 \%$ between the two sites harbouring $A$. pallipes, when the Jaccard's index is applied to E.T.P. only. This high similarity can be explained by a habitat analogy between these two sites dealing both with superficial speed ranges and substrates (coarse gravel).

Comparisons between the list of taxa of each site show that in both Thouet and Verdonnière Plecoptera, which are very sensitive to organic pollution, are only recorded at sites harbouring the white-clawed crayfish. As in the study of GRANDJEAN et al. (2001) 
(i) sites harbouring $A$. pallipes contain families of Plecoptera, (ii) there is higher family and individual richness in Trichoptera, Ephemeroptera and Diptera, particularly at sites harbouring the white-clawed crayfish than where $A$. pallipes is missing and (iii) moreover, all the sites are located near the source and so run through forested areas which would explain the high proportion of allochthonous nutrition. Thus, the occurrence of Plecoptera seems to represent a good criterion for the selection of $A$. pallipes habitat. Nevertheless, it is difficult to assume that allochthonous organic production characterizes crayfish habitats since, as a general rule, allochthonous production characterizes headstream environments.

Average values of the different physico-chemical parameters were quite similar during the study period (from November 2002 to May 2003). It is now well known that, in France, $A$. pallipes habitats are generally small forest streams with running water and with a high density of shelters such as stones, gravels and roots (ARRIGNON and ROCHE, 1983; GRANDJEAN et al., 1996, 2000; NEVEU, 2000a, b). The width of the brooks is often less than $2 \mathrm{~m}$ and the depth not more than $1 \mathrm{~m}$. Dissolved oxygen concentrations range from 7 to $10 \mathrm{mgL}^{-1}$, water temperatures do not exceed $18^{\circ} \mathrm{C}$ during summer, $\mathrm{pH}$ values are around 8 and waters present high conductivity from 200 to $600 \mu \mathrm{Scm}^{-1}$ (GRANDJEAN et al., 2001). As far as depth and width are concerned, the sites, which were studied here, fit with the ranges noted above. The $\mathrm{pH}$ values for sites harbouring the white-clawed crayfish are a bit lower than the ones measured by FOSTER (1995) (7.27-8.64) in central Wales (Great Britain) or even those obtained by GARCIA-ARBERAS and RALLO (2000) (7.958.45) in Basque Country (Spain) and by BROQUET et al. (2002) (7.45) in the Pays de Loire région. Even if it is difficult to compare dissolved oxygen measurements from different studies because this parameter is related to water temperature depending on time of day, season etc., our findings agree with those previously recorded (FOSTER, 1995; BROQUET et al., 2002). It seems also to be difficult to compare conductivity to previous studies because of its tight relation to geological substrate. Nevertheless, our conductivity values are lower than the optimal range $200-600 \mu \mathrm{Scm}^{-1}$. Our TSS values are also higher than the ones presented by BROQUET et al. (2002) $\left(7.0 \mathrm{mgL}^{-1}\right)$. TOC values appear to be higher than those measured by FOSTER (1995) (2.4-3.28 $\left.\mathrm{mgL}^{-1}\right)$. Values of TH obtained on the two sites harbouring the white-clawed crayfish are higher than the ones recorded by FOSTER (1995) (36.3 $\mathrm{mgL}^{-1} \mathrm{CaCO}_{3}$ ) on such sites. $\mathrm{NH}_{4}$ concentrations are about twice as high in the Thouet site with crayfish than in Verdonnière similar site owing to the supply of leaves from the banks. Nevertheless, these concentrations are much higher than the ones recorded by FOSTER (1995) $\left(0.007 \mathrm{mgL}^{-1}\right)$ and lower than the ones presented by GARCIAARBERAS and RALLO (2000) $\left(0.17 \pm 0.19 \mathrm{mgL}^{-1}\right)$. As far as anions $\left(\mathrm{Cl}, \mathrm{SO}_{4}, \mathrm{NO}_{3}\right.$ and $\left.\mathrm{NO}_{2}\right)$ are concerned, it is noticeable that in the case of Verdonnière $\mathrm{NO}_{3}$ concentration is higher in the site with crayfish. $\mathrm{Cl}$ and $\mathrm{NO}_{3}$ concentrations are much higher than the ones found by FOSTER (1995) (0.58-37.3 $\mathrm{mgL}^{-1}$ and $\left.0.57-4.20 \mathrm{mgL}^{-1}\right)$ and by GARCIA-ARBERAS and RALLO (2000). $\mathrm{NO}_{2}$ are low in all references. $\mathrm{SO}_{4}$ values are a bit lower than the ones recorded by FOSTER (1995) (8.77-23.6 $\left.\mathrm{mgL}^{-1}\right)$. Na and $\mathrm{K}$ concentrations in the sites harbouring $A$. pallipes appear similar to those surveyed in Basque Country by GARCIAARBERAS and RALLO (2000) (10.34 $\pm 3.53 \mathrm{mgL}^{-1}$ and $2.44 \pm 2.96 \mathrm{mgL}^{-1}$ respectively) but $\mathrm{K}$ concentrations are higher than $\mathrm{K}$ concentrations presented by FOSTER (1995) (0.25$\left.2.5 \mathrm{mgL}^{-1}\right)$.

Our results, as well as those of other authors (LAURENT, 1985; FOSTER and TURNER, 1993; TROSCHEL, 1997; BROQUET et al., 2002), show that it is difficult to establish links between the physico-chemical parameter levels and the presence or absence of crayfish. However, our results examined by PCA, reveal distinctly the predominance of crayfish according to these physico-chemical variables. The combination of chemical and biological methods constitutes a recent approach for an integrated assessment of freshwater quality. Greek studies (LAZARIDOU-DIMITRIADOU et al., 2000; KAMPA et al., 2000) have already shown that correlations between abiotic and biotic parameters using 
multivariate analyses could give a good and global assessment of freshwater quality. Finally, the clusters corresponding to the various sites are ordered according to I.B.G.N. score. This highlights, for the first time, the relationship existing between the physiochemical characteristics of water on the one hand, and the biological characteristics of the aquatic environment on the other hand.

\section{CONCLUSION}

As $A$. pallipes presence could be predicted in part by factors related to water quality but their absence or abundance could not be connected to water quality, it is becoming more and more difficult to consider this species as a bio indicator (DEMERS, 2003). This subject has also been discussed in a roundtable summarized in this present issue. It appears that a good correlation could exist between abiotic and biotic parameters and the study of more brooks could show that I.B.G.N. scores could be predicted using a PCA analysis. These first results have also shown that mineral matter did not seem to be a discriminating factor in A. pallipes presence or absence whereas organic matter appeared to be a better discriminating factor. Nevertheless, these assumptions will have to be confirmed by the study of seven other brooks from the same area actually in progress.

\section{ACKNOWLEDGEMENTS}

Special thanks are due to Julian Reynolds for his useful advice and suggestions. This work was supported by a doctoral fellowship provided by the European Programme LEADER + (La Gâtine, Château d'eau du Poitou) and was funded by the CPER (Contrat de Plan État Région) entitled "Programme transversal Eaux", University de Poitiers.

\section{REFERENCES}

AFNOR, 1992. Qualité de l'eau, Recueil des Normes Françaises, 1994. Essai des eaux. Détermination de l'indice biologique global normalisé (IBGN). NF T 90-3, 684-692.

ARRIGNON J.C., ROCHE B., 1983. Population of the crayfish Austropotamobius pallipes pallipes (Lereboullet) in a brook of Corsica (France). Freshwater Crayfish, V, 229238.

BAILLIE J., GROOMBRIDGE B., 1996. IUCN Red list of threatened animals. Gland, Switzerland: IUCN.

BROQUET T., THIBAULT M., NEVEU A., 2002. Distribution and habitat requirements of the white-clawed crayfish, Austropotamobius pallipes, in a stream from the Pays de Loire region, France: an experimental and descriptive study. Bull. Fr. Pêche Piscic., 367, 717-728.

CHARVET S., 1995. Les méthodes biologiques d'évaluation de la qualité des eaux basées sur les macro invertébrés benthiques. Rapport bibliographique. Diplôme d'Études Approfondies, Analyse et modélisation des systèmes biologiques. Université de Lyon I, $39 \mathrm{p}$.

DALE V.H., BEYELER S.C., 2001. Challenges in the development and use of ecological indicators. Ecological Indicator, 1, 3-10.

DELVALLE J., BOUTET L., BRAMARD M., 2002. Étude biologique du Thouet Amont. Rapport interne, Conseil Supérieur de la Pêche, Délégation Régionale, 15, 49 p.

DEMERS A., 2003. The water quality requirements of white-clawed crayfish, Austropotamobius pallipes (Lereboullet). Thesis, University of Dublin, Trinity College. 234 p. 
DEMERS A., REYNOLDS J.D., 2002. A survey of the white-clawed crayfish, Austropotamobius pallipes (Lereboullet), and of water quality in two catchments of eastern Ireland. Bull. Fr. Pêche Piscic., 367, 729-740.

FOSTER J., 1995. Factors influencing the distribution and abundance of the crayfish Austropotamobius pallipes (Lereboullet) in Wales and the Marches, UK. Freshwater Crayfish, VIII, 78-98.

FOSTER J. and TURNER C., 1993. Toxicity of field simulated farm waste episodes to the crayfish Austropotamobius pallipes (Lereboullet): elevated ammonia and reduced dissolved oxygen concentrations. Freshwater crayfish, IX, 249-258.

GARCIA-ARBERAS L. and RALLO A., 2000. Survival of natural populations of Austropotamobius pallipes in rivers in Biscay, Basque country (north of Iberian peninsula). Bull. Fr. Pêche Piscic., 356, 17-30.

GRANDJEAN F., BRAMARD M., SOUTY-GROSSET C., 1996. Distribution and proposal for the conservation of the indigenous freshwater crayfish species, Austropotamobius pallipes pallipes, in a French department. Freshwater Crayfish, 11, 655-664.

GRANDJEAN F., CORNUAULT B., ARCHAMBAULT S., BRAMARD M., OTREBSKY G., 2000. Life history and population biology of the white-clawed crayfish, Austropotamobius pallipes pallipes, in a brook from The Poitou-Charentes region (France). Bull. Fr. Pêche Piscic., 356, 55-70.

GRANDJEAN F., JOUTEUX R., ROPIQUET A., BACHELIER E., BRAMARD M., 2001. Biological water quality assessment in running waters sites harboring the endangered crayfish, Austropotamobius pallipes based on macroinvertebrates and its potential in habitat selection for restocking. Freshwater Crayfish, XIII, 338-348.

HOLDICH D.M., 2002. Distribution of crayfish in Europe and some adjoining countries. Bull. Fr. Pêche Piscic., 367, 611-650.

HOLDICH D.M. and ROGERS W.D., 1997. The white-clawed crayfish, Austropotamobius pallipes, in Great Britain and Ireland with particular reference to its conservation in Great Britain. Bull. Fr. Pêche Piscic., 347, 597-616.

KAMPA E., ARTEMIADOU V., LAZARIDOU-DIMITRIADOU M., 2000. Ecological quality of the River Axios (N. Greece) during spring and summer, 1997. Belg. J. Zool., 130, 21-27.

LAURENT P.J., 1985. Une station d'écrevisses à pieds blancs: Austropotamobius pallipes Lere. (Decapoda-Astacidae) en zone périurbaine. Bulletin de la société linnéenne de Lyon, 3, 77-88.

LAZARIDOU-DIMITRIADOU M., ARTEMIADOU V., YFANTIS G., MOURELATOS S., MYLOPOULOS Y., 2000. Contribution to the ecological quality of Aliakmon river (Macedonia, Greece): a multivariate approach. Hydrobiologia, 410, 47-58.

MERRIT R.W. and CUMMINS K.W., 1996. An introduction to the Aquatic Insects of North America, $3^{\text {rd }}$ edition. Kendall-Hunt Publishing Co., Dubuque, lowa.

NEVEU A., 2000a. Étude des populations d'Austropotamobius pallipes (Crustacea, Astacidae) dans un ruisseau forestier de Normandie. I. Structures démographiques et croissance: stabilité et variété au cours de six années. Bull. Fr. Pêche Piscic., 356, 71-98.

NEVEU A., 2000b. Étude des populations d'Austropotamobius pallipes (Crustacea, Astacidae) dans un ruisseau forestier de Normandie. II. Répartition en fonction de 
la structure des habitats: stabilité et variabilité au cours de cinq années. Bull. Fr. Pêche Piscic., 356, 99-122.

TROSCHEL H.J., 1997. Distribution and ecology of Austropotamobius pallipes in Germany. Bull. Fr. Pêche Piscic., 347, 639-647.

VERNEAUX J., GALMICHE P., JANIER F., MONNOT A., 1983. Une nouvelle méthode pratique d'évaluation de la qualité des eaux courantes. Un indice biologique de qualité générale (IBG). Annales Scientifiques de I'Université, Besançon, Biologie Animale (4), 3, 11-21.

VIGNEUX E., 1997. Les introductions de crustacés décapodes d'eau douce en France. Peut-on parler de gestion ? Bull. Fr. Pêche Piscic., 344/345, 357-370. 